Ann. Biol. anim. Bioch. Biophys., 1979, 19 (5), 1613-1617.

\title{
Effect of the donor on egg quality and transfer results
}

\author{
par J. HAHN, U. SCHNEIDER \\ Klinik für Geburtshilfe und Gynäkologie des Rindes \\ der Tierärzflichen Hochschule Hannover, Bischofsholer Damm 15, 3000 Hannover, West Germany \\ Abteilung für Experimentelle Fortpflanzungsbiologie.
}

\begin{abstract}
Summary. Embryo transfer with high-producing animals as donors led to new problems. Optimal results depended on a strict preselection of donors. Animals with a) a critical anamnesis, b) a calving-superovulation interval of more than 90 days, or c) from herds with decreased fertility should be carefully evaluated prior to superovulation and embryo transfer. The advantage of preselected donors is that the proportion of morphologically damaged embryos is less and therefore the chance of misjudging embryo quality is lower. Even if the preselection of donors is possible, the use of high producing cows with critical anamnesis cannot be avoided in certain cases, especially if the owner wants to use such animals. A better selection of embryo viability might occur naturally if the embryos were recovered on days 10 to 12 instead of on day 7 . However, the uterine conditions for embryonic survival worsen steadily after day 4 . This embryonic loss cannot be tolerated, especially in very valuable cows. Also, tranfer results of 75 p. 100 or higher could apparently not be obtained with older embryos. The problems discussed force us to search for criteria other than morphological appearance for judging the viability of day 7 embryos.
\end{abstract}

\section{Introduction.}

Through the improved technique of non-surgical embryo recovery and nonsurgical or surgical ova transfer, bovine embryo transfer has reached the phase where it can be applied to animal breeding practice.

In order to compensate for the considerable cost arising from embryo transfer work - which has been approximately calculated in various countries - and to realize the advantages of this technique for animal breeding, only high-yielding cows with excellent pedigree should be selected from among the possible donor animals.

German breeders were primarily sceptical of this new biotechnical method, so that only a few of the animals needed were available in 1975/76 and 1976/77. However, in the latter part of $1977 / 78$, we received valuable donor animals to be used in embryo transfer. The team of the Veterinary School in Hannover works in two transfer stations. One, in the north near Bremerhaven, only has donors of the German Friesian and Holstein Friesian breeds. In the other transfer station, located in southern Germany near Neustadt a.d. Aisch (between Würzburg and Nürnberg), the donors are 
mainly Simmental. Both transfer stations are managed by the two largest A. I. organizations.

The breeder in the north who wants to multiply the number of offspring of a particular cow in his breeding herd, chooses the donor animal himself. He therefore has to bear the entire cost of the transfer work.

In the south a breeding association in collaboration with the A.l. organization selects donors from the various breeders; the donor cow is actually leased from the breeder. The cost of the transfer is partly covered by the breeding association and partly by the A.I. organisation. Both organizations are also responsible for subsequent fertility of the donor after ova recovery. The various reasons for the different selection procedures will not be discussed in detail here. One reason, however, is the price difference between a top performance cow of the Holstein Friesian breed and one of the Simmental breed.

These different methods of selecting donor animals are thus such that in northern Germany the donors are not preselected, while in the south they are carefully chosen.

Selection, preparation, breed and age of the recipients plus the transfer technique are more or less the same in both stations.

\section{Results.}

Table 1. - In group 1, all the 58 animals studied were superovulated. They annually produced up to $8000 \mathrm{~kg}$ of milk. In $42(72 \mathrm{p.} \mathrm{100)}$ of the animals, four or more corpora lutea $(C L)$ were diagnosed by rectal palpation. A total of 251 embryos were collected ; 162 (65 p. 100) of the embryos were judged morphologically normal and were subsequently transferred. The pregnancy results of the 65 surgically transferred embryos reached 58 p. 100 , whereas that of the 97 non-surgically transferred embryos reached 33 p. 100.

\section{TABLE 1}

Transfer results $1977 / 78$ Group $1=$ German Friesian, Group $2=$ Fleckvieh (Simmental). Superovulation treatment $=\mathrm{FSH}$, Embryo collection $=\mathrm{D}_{7}$

\begin{tabular}{|c|c|c|c|c|c|c|c|c|c|}
\hline & \multirow[b]{2}{*}{$\begin{array}{l}\text { Donors } \\
\text { studied }\end{array}$} & \multirow[b]{2}{*}{$\begin{array}{l}\text { Donors } \\
\text { super- } \\
\text { ovulated }\end{array}$} & \multirow[b]{2}{*}{$\begin{array}{l}\text { Donors } \\
\geqslant 4 \mathrm{CL} \\
(\text { p. } 100)\end{array}$} & \multirow[b]{2}{*}{$\begin{array}{c}\text { No. collected } \\
\text { embryos }\end{array}$} & \multirow{2}{*}{$\begin{array}{l}\text { No. trans- } \\
\text { ferred } \\
\text { embryos } \\
\text { (p. 100) }\end{array}$} & \multicolumn{4}{|c|}{ Results of transfer } \\
\hline & & & & & & $\begin{array}{r}\text { sur } \\
\text { No. } F \\
\text { (p. }\end{array}$ & $\begin{array}{l}\text { gical } \\
\text { regn. } \\
100)\end{array}$ & $\begin{array}{r}\text { non-s } \\
\text { No. } \\
\text { (p. }\end{array}$ & $\begin{array}{l}\text { urgical } \\
\text { Pregn. } \\
100)\end{array}$ \\
\hline $\begin{array}{l}1 \\
2\end{array}$ & $\begin{array}{l}58 \\
39\end{array}$ & $\begin{array}{l}58 \\
19\end{array}$ & $\begin{array}{l}42(72) \\
15(80)\end{array}$ & $\begin{array}{r}251 \\
76\end{array}$ & $\begin{array}{r}162(65) \\
66(87)\end{array}$ & $\begin{array}{l}65 \\
65\end{array}$ & $\begin{array}{l}58 \\
75\end{array}$ & $\begin{array}{r}97 \\
1\end{array}$ & $\begin{array}{r}33 \\
100\end{array}$ \\
\hline
\end{tabular}

From the 39 possible donor animals in group 2, only 19 were selected as donors and superovulated. They annually produced up to $6000 \mathrm{~kg}$ of milk. From the remaining 20 animals that were not used as donors, 80 p. 100 were diagnosed as having fertility problems such as ovarian cysts, genital catarrh and shortened or extended cycles. Of the 19 superovulated animals, $15(80$ p. 100$)$ had 4 or more CL. Seventy-six embryos 
were recovered non-surgically from the latter, and 66 (87 p. 100) were transferable. Of the 65 surgical transfers, 75 p. 100 remained pregnant. In addition, 3 abortions were observed in this group.

Thus, a reduction of transfer success was apparent in group 1, while optimal results (75 p. 100) were obtained in group 2.

Table 2. - Data on the course of the puerperium of the donors were collected retrospectively in group 1 . The survey showed that of the 16 animals with insufficient ovarian response to superovulation treatment $(<4 \mathrm{CL}), 12$ had a critical anamnesis. Only a mean of 0.4 embryos were recovered from these 16 donors. It is thus apparent that the superovulation response is influenced by the fertility and the health status of the donor animal.

TABLE 2

Anammesis of superovulated donors (Group $1=$ German Friesian)

\begin{tabular}{|c|c|c|c|c|}
\hline \multirow{2}{*}{$\begin{array}{l}\text { Superovulatory } \\
\text { response }\end{array}$} & \multicolumn{2}{|c|}{ Anamnesis } & \multirow{2}{*}{$\begin{array}{c}\text { Total } \\
\text { No. donors }\end{array}$} & \multirow{2}{*}{$\begin{array}{c}\text { No. embryos } \\
\text { per donor }\end{array}$} \\
\hline & regular & critical * & & \\
\hline $\begin{array}{l}\geqslant 4 \mathrm{CL} \\
<4 \mathrm{CL}\end{array}$ & $\begin{array}{r}33 \\
4\end{array}$ & $\begin{array}{r}9 \\
12\end{array}$ & $\begin{array}{l}42 \\
16\end{array}$ & $\begin{array}{l}6.0 \\
0.4\end{array}$ \\
\hline
\end{tabular}
diseases.

* Dystocia, puerperal disturbances, postpuerperal fertility problems, postparturient metabolic

Of interest are the transfer results of the animals with a good ovarian reaction $(>4 \mathrm{CL})$, dependent on regular or critical anamnesis.

Table 3. - This table shows that the mean number of embryos recovered was lower after flushing the donors with a critical anamnesis (4.7 vs. 6.3). Also, the transfer results of embryos from donors with critical anamnesis were considerably lower. It should be pointed out that only those embryos which appeared morphologically normal were transferred. Therefore, it seems that embryos from healthy donors survive far better than those from donors with fertility problems.

Of interest are the transfer results as correlated with the calving-induced superovulation interval.

TABLE 3

Transfer results Donors $\geqslant 4 \mathrm{CL}$ (Group $1=$ German Friesian) ; anamnesis : regular and critical

\begin{tabular}{|c|c|c|c|c|c|}
\hline \multirow[b]{2}{*}{ Anamnesis } & \multirow[b]{2}{*}{ No. donors } & \multirow[b]{2}{*}{$\begin{array}{l}\text { No. collected } \\
\text { embryos }\end{array}$} & \multirow{2}{*}{$\begin{array}{l}\text { No. trans- } \\
\text { ferred } \\
\text { embryos } \\
\text { (p. 100) }\end{array}$} & \multicolumn{2}{|c|}{ Results of transfer } \\
\hline & & & & $\begin{array}{l}\text { surgical } \\
\text { No. Pregn. } \\
\text { (p. 100) }\end{array}$ & $\begin{array}{l}\text { non-surgical } \\
\text { No. Pregn. } \\
\text { (p. 100) }\end{array}$ \\
\hline $\begin{array}{l}\text { Regular ........ } \\
\text { Critical. ........ }\end{array}$ & $\begin{array}{r}33 \\
9\end{array}$ & $\begin{array}{r}208 \\
43\end{array}$ & $\begin{array}{r}127(61) \\
35(81)\end{array}$ & $\begin{array}{rr}59 & 59 \\
6 & 50\end{array}$ & $\begin{array}{ll}68 & 41 \\
29 & 14\end{array}$ \\
\hline
\end{tabular}


Table 4. - The transfer results were significantly lower when the embryo was recovered after 90 days postpartum. The number of animals with critical anamnesis was equally distributed between the two groups. If the animals with critical anamnesis are excluded from the group superovulated within 90 days $p$. p., the results increase to 70 p. 100 after surgical transfer, and to 55 p. 100 after non-surgical transfer.

TABLE 4

Transfer results Donors $\geqslant 4 \mathrm{CL}$ (Group $1=$ German Friesian) ; superovulation treatment p. p. ; < 90 days and $>90$ days

\begin{tabular}{|c|c|c|c|c|c|}
\hline \multirow[b]{2}{*}{$\begin{array}{l}\text { Superovulation } \\
\text { treatment } \\
\text { days p. p. }\end{array}$} & \multirow[b]{2}{*}{ No. donors } & \multirow[b]{2}{*}{$\begin{array}{c}\text { No. collected } \\
\text { embryos }\end{array}$} & \multirow{2}{*}{$\begin{array}{l}\text { No. trans- } \\
\text { ferred } \\
\text { embryos } \\
\text { (p. 100) }\end{array}$} & \multicolumn{2}{|c|}{ Results of transfer } \\
\hline & & & & $\begin{array}{l}\text { surgical } \\
\text { No. Pregn. } \\
\text { (p. 100) }\end{array}$ & $\begin{array}{l}\text { non-surgical } \\
\text { No. Pregn. } \\
\text { p. 100) }\end{array}$ \\
\hline $\begin{array}{l}<90 \\
>90\end{array}$ & $\begin{array}{l}27 \\
15\end{array}$ & $\begin{array}{l}150 \\
101\end{array}$ & $\begin{array}{r}103(69) \\
59(58)\end{array}$ & $\begin{array}{ll}51 & 67 \\
14 & 29\end{array}$ & $\begin{array}{ll}52 & 42 \\
45 & 22\end{array}$ \\
\hline
\end{tabular}

Table 5. - This table shows the transfer success of the donors from different herds. Data on the donors of three different farms have been assessed so far. All three farms are top breeders with very high milk production. Some of the animals studied were superovulated more than once. Leaving aside such factors as anamnesis and the calving-superovulation interval, the data show a decline of transfer success from herd 1 to herd 3. Again it should be noted that only morphologically normal embryos were transferred. Also, the percentage of transferable embryos, which is closely related to the number of morphologically normal embryos, indicates a difference in egg quality between the different herds.

TABLE 5

Transfer results

Donors $\geqslant 4 \mathrm{CL}$ (Group $1=$ German Friesian) originating from 3 different herds

\begin{tabular}{|c|c|c|c|c|c|c|}
\hline \multirow{3}{*}{$\frac{\text { Herd }}{1}$} & \multirow{3}{*}{$\begin{array}{c}\text { No. donors } \\
7\end{array}$} & \multirow{3}{*}{$\begin{array}{c}\begin{array}{c}\text { No. collected } \\
\text { embryos }\end{array} \\
43\end{array}$} & \multirow{3}{*}{$\begin{array}{c}\begin{array}{c}\text { No. transferred } \\
\text { embryos } \\
\text { (p. 100) }\end{array} \\
32(74)\end{array}$} & \multicolumn{3}{|c|}{ Results of transfer } \\
\hline & & & & $\begin{array}{c}\text { surgical } \\
\text { No. Pregn. } \\
\text { (p. 100) }\end{array}$ & \multicolumn{2}{|c|}{$\begin{array}{c}\text { non-surgical } \\
\text { No. Pregn. } \\
\text { (p. 100) }\end{array}$} \\
\hline & & & & 1656 & 16 & 50 \\
\hline 2 & 20 & 119 & $72(61)$ & $27 \quad 48$ & 45 & 44 \\
\hline 3 & 6 & 32 & $17(53)$ & 667 & 11 & 0 \\
\hline
\end{tabular}

It appears that farm management (the importance of feeding, animal health care, eic.) is a factor influencing bovine embryo transfer work.

EEC Seminar on « Ovarian stimulation and egg quality in mammals », Luynes, France, octobre 1978. 
Résumé. Un transfert d'embryons à partir d'animaux de haut niveau de production comme donneurs conduit à de nouveaux problèmes. Les résultats optima dépendent d'une pré-sélection stricte des donneurs. Les animaux avec $: a)$ une anamnèse crifique ou b) plus de 90 jours d'intervalle entre vélage et superovulation c) provenant de troupeaux avec fertilité décroissante, sont soigneusement détectés avant superovulation ou transfert d'embryon.

L'avantage de donneuses pré-sélectionnées est que la proportion d'embryons morphologiquement endommagés est moindre et, par conséquent, la chance de mal juger de la qualité de l'embryon est plus faible. Même si une pré-sélection de donneuses est possible, l'utilisation de vaches forte productrices avec une anamnèse critique ne peut être évitée dans certains cas, spécialement si le propriétaire veut employer un tel animal.

Une meilleure sélection de la viabilité de l'embryon peut arriver de façon naturelle quand les embryons sont prélevés aux jours 10-12 au lieu du jour 7 . Cependant, il est bien connu que dans l'utérus les conditions de survie des embryons deviennent pires chaque jour après le jour 4 . Cette perte des embryons ne peut être tolérée, en particulier pour des vaches très intéressantes. Des résultats de transfert de 75 p. 100 et plus ne peuvent pas être obtenus avec des embryons plus âgés.

Les problèmes discutés nous obligent à rechercher des techniques complémentaires pour juger de la viabilité des embryons le jour 7, autrement que sur l'apparence morphologique. 